911.3

\author{
- ог дьоров \\ ерсонський держ вний університет, \\ вул. 40 років овтня, 27, м. ерсон, 73000, кр їн
}

осліджено територі льну орг ніз цію особистих господ рств н селення н лок льному рівні. підст ві дослідження суспільно-геогр фічних т природно-екологічних чинників розвитку особистих господ рств ерсонської обл., н лізу г лузевої структури, специфіки землекористув ння, проведено типологічне зонув ння території ерсонської обл. $з$ особливостями розвитку т функціонув ння господ рств.

лючові слов : особисті господ рств н селення, територі льн орг ніз ція, , спеці ліз ція, землекористув ння.

суч сному ет пі нез перечним є той ф кт, що з роки гр рної тр нсформ ції в кр їні з фіксов н низк нег тивних тенденцій у землекористув нні т сільськогоспод рському виробництві кр їни з г лом. о т ких тенденцій можн з числити: зниження продуктивності рослинництв, різке скорочення поголів'я тв рин, з гострення екологічної ситу ції в сфері землекористув ння тощо. роте викон ні економіст ми- гр рник ми дослідження щодо порівняльної оцінки продуктивності особистих господ рств н селення ( ) свідч ть, що ці господ рств , м ючи порівняно із сільгосппідприємств ми мізерні м сшт би з земельною площею т кількістю утримув них тв рин і виконуючи м йже всі сільськогоспод рські роботи вручну (винятк ми є окремі види робіт, н йч стіше - це ор нк ділянок), досяг ють вищих пок зників урож йності сільськогоспод рських культур і продуктивності тв рин.

вич йно, з зн чені нег тивні тенденції щодо розвитку сільськогоспод рського виробництв х р ктерні для господ рств як суспільного, т к і прив тного сектор , зокрем , особистих господ рств. роте з'ясов но, що головним чинником зниження продуктивності рослинництв в господ рств х н селення з роки гр рних тр нсформ цій був структурний, зокрем, погіршення (з позицій продуктивності) структури посівів н орних землях, т кож б г торічних плодово-ягідних н с джень. ниження питомої продуктивності рослинництв в цих господ рств х ун слідок погіршення структури землекористув ння зумовлене н $75 \%$, вн слідок зменшення врож йності сільськогоспод рських культур - н $25 \%$. З зн чимо, що в господ рств х н селення знижув л ся врож йність лише сільськогоспод рських культур, вирощув них н орних землях. родуктивність $б$ г торічних плодово-ягідних н с джень, н вп ки, зрост л .

сільськогоспод рських підприємств х основною причиною зменшення продуктивності рослинництв було зниження врож йності сільськогоспод рських культур. им чинником зумовлено м йже дві третини зниження питомої продуктивності рослинництв , структурним - дещо більше однієї третини.

(C) ог дьоров ., 2010 
ст нніми десятиліттями, з огляду н розуміння 6 г тогр нної т щор з в жливішої ролі сільських територій у соці льно-економічному розвитку регіонів, широке коло н уковців і спеці лістів-пр ктиків, орг ни держ вного упр вління т місцевого с моврядув ння, різні гром дські орг ніз ції й уст нови приділяють більше ув ги пит нням вивчення т кл сифік ції кту льних проблем б г тофункціон льного розвитку сільських територій і розробки конкретних мех нізмів їхнього вирішення.

ільшість н уковців підтримує думку про те, що вдоскон лення територі льної орг ніз ції виробництв перев жно спрямов не одноч сно н $\mathrm{p}$ ціон ліз цію т підвищення ефективності використ ння н явного природно-ресурсного потенці лу ( ).

е відбув ється з вдяки територі льному розподілу пр ці, спеці ліз ції виробництв , p ціон льному використ нню природних умов т ресурсів, удоскон ленню виробничотериторі льних зв'язків т ін.

дн к н голосимо, що територі льн орг ніз ція т з ходи для її вдоскон лення зводяться не тільки до природокористув ння. ериторі льн орг ніз ція охоплює 6 г то пит нь економічного, технологічного, соці льного, орг ніз ційного х р ктеру, безпосередньо не пов'яз них зі спожив нням природних ресурсів і використ нням природних умов.

ціон льн територі льн орг ніз ція поряд з доцільним використ нням природних умов $\mathrm{T}$ ресурсів спрямов н p вління розвитком т ких форм господ рюв ння, поліпшення економіки й технології виробництв т промислової переробки продукції

зн чимо, що виявлення особливостей територі льної орг ніз ції передб ч $є$ проведення відповідного зонув ння території регіону і типіз ції 3 особливостями спеці ліз ції т х р ктерними рис ми використ ння території. ке зонув ння, н н ш погляд, методично є досить специфічним, зв ж ючи н незн чну площу більшості регіонів кр їни т особливості ст тистичної б зи дослідження. к методичний досвід т кого зонув ння н ведемо м тері ли роботи, викон ної н ми по ерсонському регіону. меж х досліджув ної території виробляється зн чн ч стк сільськогоспод рської продукції кр їни - це кл сичний гр рно-індустрі льний регіон кр їни, крім того, зн чн ч стк земель (пон д $23 \%$ ) перебув є в особистому господ рюв нні, 3 окремими вид ми продукції (н прикл д, тв ринницької) є провідними виробник ми в гр рній сфері регіону.

підст ві н лізу територі льної орг ніз ції, спеці ліз ції т природокористув ння у меж $\mathrm{x}$ ерсонщини можемо кцентув ти, що різном ніття регіонів обл сті 3 природно-екологічними чинник ми, л ндш фтною структурою, соці льно-економічними чинник ми (спеці ліз ція сільськогоспод рського виробництв, рівень урб ніз ції, розвиток інфр структури тощо) зумовлює диференці цію режимів природокористув ння в і потребує принципово різних підходів у н прям х сільськогоспод рського виробництв , його спеці ліз ції, територі льній орг ніз ції.

и н 3 с д $\mathrm{x}$ дослідження суспільно-геогр фічних т природно-екологічних чинників розвитку ерсонської обл., н лізу г лузевої структури, специфіки землекористув ння, провели типологічне зонув ння території ерсонської обл. 3 особливостями розвитку т функціонув ння особистих господ рств (див. рисунок).

ослідження територі льної орг ніз ції н рівні виділених зон і типів д $є$ змогу н зв ти основні особливості розвитку, спеці ліз ції т специфіки природокористув ння особистих господ рств у їхніх меж х (т бл. 1). 


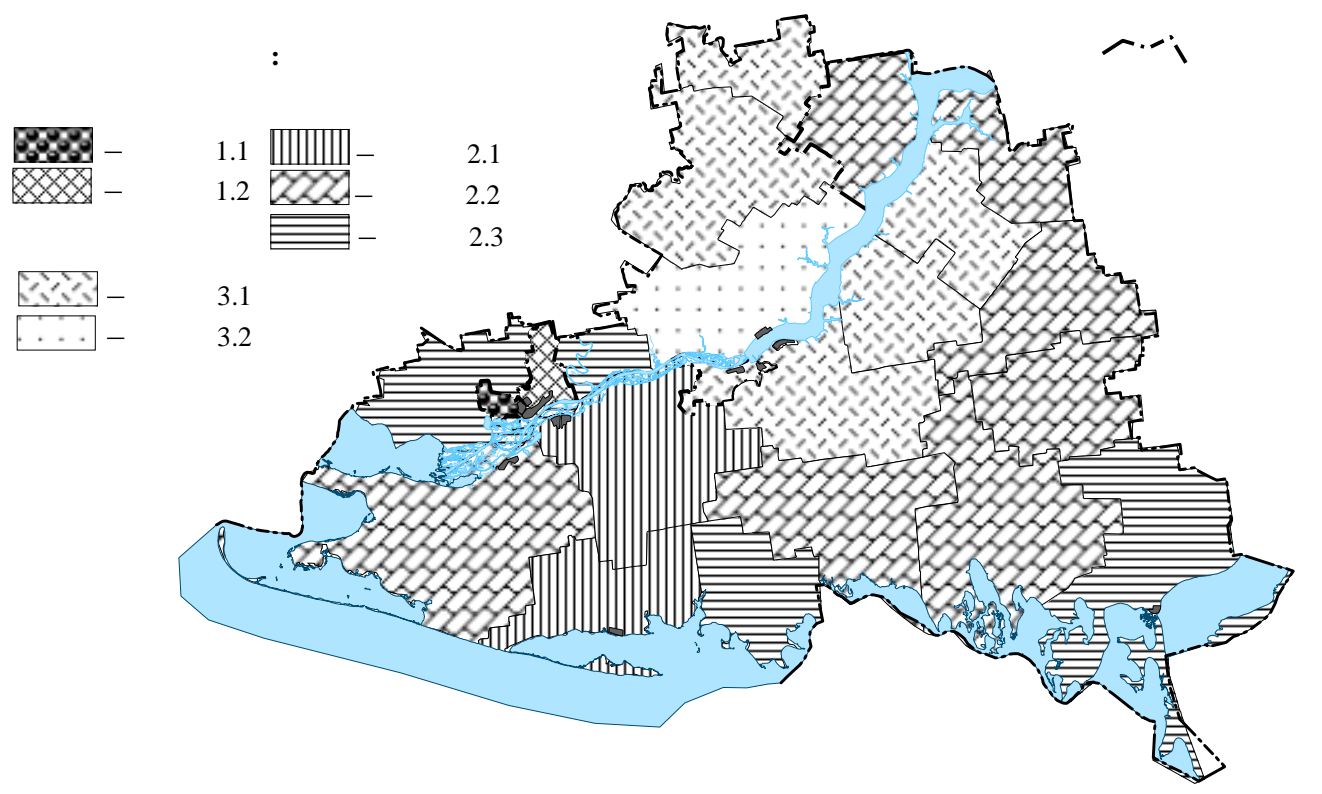

ис. 1. ипологічне зонув ння ерсонської обл. з особливостями функціонув ння і територі льної орг ніз ції

одноч с н голосимо, що під ч с зонув ння в жливо вр ховув ти і відобр ж ти особливості соці льно-економічних т природно-екологічних умов тієї території, у меж х якої функціонують особисті господ рств того чи іншого типу.

ип : приміський. о цього типу н леж ть міст ерсон т ов ховк . ей тип 3 спеці ліз цією т інтенсивністю розвитку відрізняється перш з все н дзвич йно високою територі льною лок ліз цією овочевих культур т к ртоплі (коефіцієнти лок лі3 ції ст новлять, відповідно, 6,54 т 1,79). ля типу є х р ктерною середня для обл сті ч стк земель, з йнятих під особисті господ рств н селення (коефіцієнт лок ліз ції 0,95). рит м нним $є$ незн чний розвиток тв ринництв, кількість голів худоби н особу втричі менш, ніж середньообл сний пок зник. одноч с у скот рстві простежен н йвищ в ерсонському регіоні ч стк корів, як ст новить $84 \%$ від чисельності великої рог тої худоби цього типу. ричин ми формув ння т кої спеці ліз ції $\epsilon$, головно, орієнт ція н міського спожив ч .

ля типу х р ктерною є висок інтенсивність природокористув ння і зн чний рівень тр нсформ ції грол ндш фтів, що пояснюють т кими чинник ми: регіон м, що н леж ть до цього типу, прит м нн висок щільність н селення (до 400 осіб н $1 \mathrm{kм}^{2}$ сільських мешк нців); н явн рослинницьк спеці ліз ція (овочівництво і к ртоплярство) відрізняється високим рівнем меліор тивного втруч ння людини під ч с сільськогопод рського виробництв ; зв ж ючи н високу щільність н селення, особливості кон'юнктури ринку і зручне геогр фічне положення щодо центрів споживчого попиту, для типу х р ктерною є висок цін земельних ділянок, що посилює інтенсивність використ ння землі, як вже є в особистому господ рюв нні. 
блиця 1

пеці ліз ція сільськогоспод рського виробництв в меж х типологічних одиниць

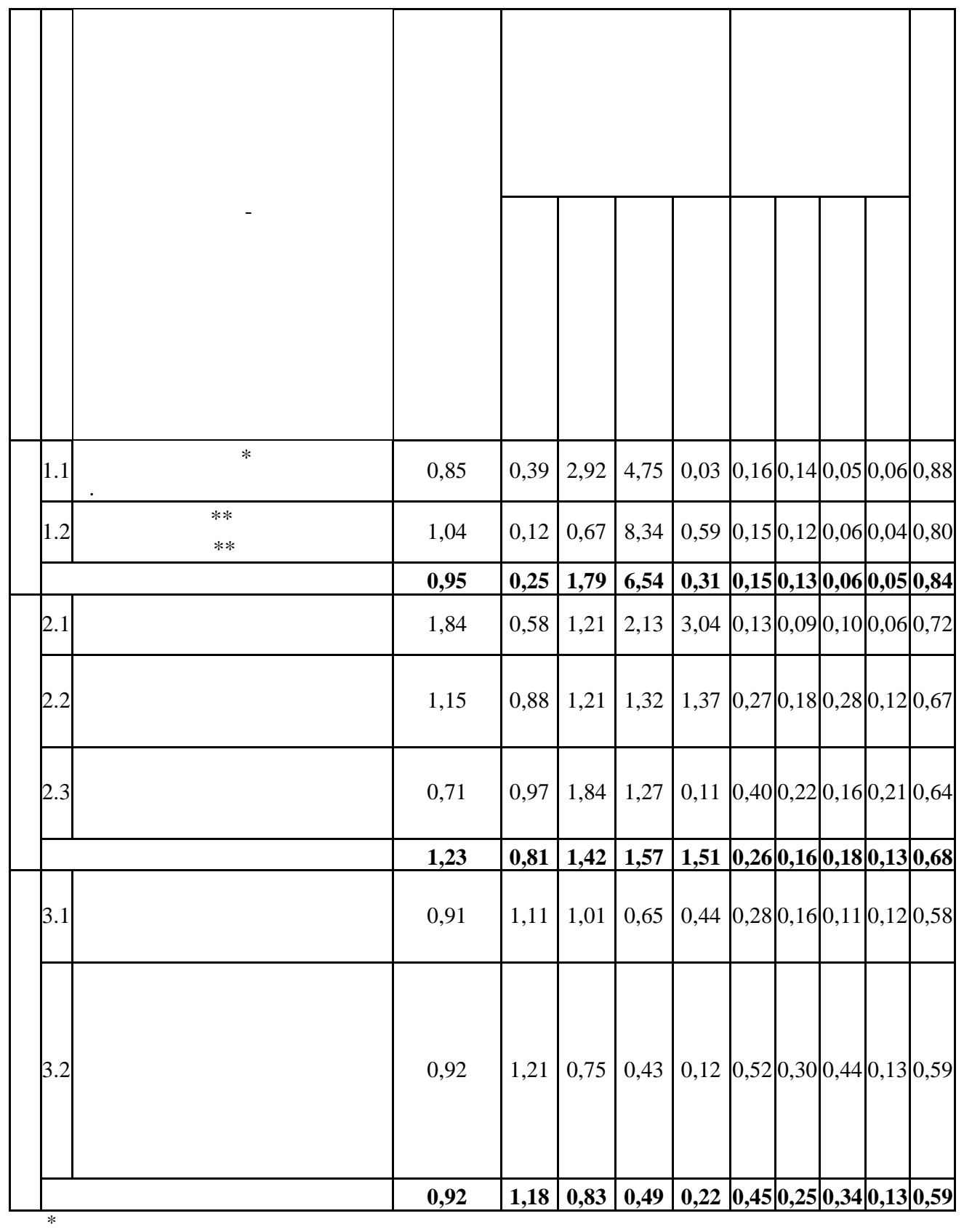
обл сного упр вління ст тистики.

** йони, що н леж ть до м. ерсон . 
iдmun 1.1. о скл ду підтипу н леж ть омсомольський р йон м. ерсон т м. ов ховк . і території відрізняються т кими особливостями: меншою ч сткою

в структурі сільськогоспод рського землекористув ння (коефіцієнт лок ліз ції 0,85); дуже високим (н йвищий в ерсонському регіоні пок зник) коефіцієнтом лок ліз ції м сивів вирощув ння к ртоплі - 2,92; нижчим щодо середнього по типу (т все ж т ки дуже високим) пок зником концентр ції овочевих культур - 4,75; прит м нним $€$ н йнижчий в обл сті пок зник лок ліз ції 6 шт нних культур - 0,03; ч стк корів щодо з г льної кількості великої рог тої худоби більш від середнього типу пок зник і ст новить $88 \%$.

iдmun 1.2. о цього підтипу н леж ть ніпровський т уворовський $\mathrm{p}$ йони м. ерсон . собливості підтипу визн чені т кими спект ми: н дзвич йно висок моноспеці ліз ція н вирощув нні овочевих культур (коефіцієнт територі льної лок ліз ції - 8,34); трохи вищим від середнього рівнем розвитку (коефіцієнт лок ліз ції $1,84) ;$ х р ктерним є дост тньо високий рівень лок ліз ції $(0,59)$ б шт нних культур, що м йже в 2 р зи вищий від середньотипового пок зник, бо в 20 р зів вищий, ніж пок зник підтипу 1.1; ч стк корів щодо з г льної кількості великої рог тої худоби менш від середнього для типу пок зник і ст новить $80 \%$.

ип : н півпериферійний. икон н кл стериз ція д л змогу поєдн ти в цей тип т кі дміністр тивні р йони ерсонської обл.: ілозерський, енічеський, олоприст нський, л нч цький, ововоронцовський, овотроїцький, к довський, юрупинський.

собливістю розвитку і функціонув ння же висок ч стк земель, сконцентров них в

в меж х цього типу є, передусім, ду(н $23 \%$ більш від середньообл сного пок зник ). рит м нною є спеці ліз ція н вирощув нні к ртоплі, овочевих і 6 шт нних культур.

одо першого типу спостеріг ють певні зміни у розвитку тв ринництв . прикл д, зрост є м йже вдвічі поголів'я великої рог тої худоби в розр хунку н особу. одноч с відносн ч стк корів у поголів'ї зменшується з 84 до $68 \%$ у середньому по типу, що пов'яз но, н н шу думку, зі зменшенням попиту н молочну продукцію вн слідок відд леності від урб нізов них регіонів обл сті. томість, м йже в 2,6 р 3 збільшується концентр ція поголів'я м лої рог тої худоби (коефіцієнт лок ліз ції зрост є 30,05 до 0,13). рім того, втричі зрост є поголів'я свиней у розр хунку н особу, що пояснюють зрост нням м йже в 3,3 р з (з 0,25 до 0,81) коефіцієнт лок ліз ції зернових культур.

ля регіону з г лом х р ктерною особливістю природокористув ння $€$ н явність зн чних м сивів зрошув них земель, що вплинуло н формув ння спеці ліз ції рослинництв . роте н голосимо, що зрошення, н н шу думку, посилило нег тивні гідрогеологічні процеси, які відбув ються н цих територіях. окрем, у більшості з зн чених регіонів перев жн ч стк земель (в тому числі й земель ) підтоплен (т бл. 2). одноч с, посилення нег тивних гідрогеологічних процесів призводить, як звич йно, до скорочення ріллі в структурі сільськогоспод рських угідь, що сприяє збільшенню кормової б зи скот рств і зменшуе нтропогенне н в нт ження н землі регіону.

н слідок різном ніття регіонів, що утворюють цей тип, з природно-екологічними чинник ми, л ндш фтною структурою, соці льно-економічними чинник ми (спеці лі3 ція сільськогоспод рського виробництв, рівень урб ніз ції, розвиток інфр структури тощо), особливостями природокористув ння в його меж х доцільно виділяти три підтипи. 
лощі підтоплення по дміністр тивних р йон $\mathrm{x}$ н півпериферійного типу

\begin{tabular}{|c|c|c|}
\hline ЙоН & $\begin{array}{l}\text { стк зрошув них земель від } \\
3 \text { г льної площі р йону, \% }\end{array}$ & $\begin{array}{l}\text { стк підтоплених земель від } \\
\text { з г льної площі р йону, \% }\end{array}$ \\
\hline \multicolumn{3}{|c|}{ ідтип 2.1} \\
\hline $\begin{array}{l}\text { к довський } \\
\text { юрупинський }\end{array}$ & $\begin{array}{l}42,3 \\
22,7\end{array}$ & $\begin{array}{l}56,4 \\
61,0\end{array}$ \\
\hline \multicolumn{3}{|c|}{ ідтип 2.2} \\
\hline $\begin{array}{l}\text { олоприст нський } \\
\text { ововоронцовський } \\
\text { овотроїцький }\end{array}$ & $\begin{array}{c}26,5 \\
8,3 \\
39,7 \\
\end{array}$ & $\begin{array}{l}55,1 \\
25,8 \\
91,1 \\
\end{array}$ \\
\hline \multicolumn{3}{|c|}{ ідтип 2.3} \\
\hline $\begin{array}{l}\text { ілозерський } \\
\text { енічеський } \\
\text { л нч цький }\end{array}$ & $\begin{array}{l}29,1 \\
19,0 \\
28,3\end{array}$ & $\begin{array}{c}5,5 \\
21,2 \\
29,0\end{array}$ \\
\hline
\end{tabular}
обл сті" - дес : ричорноморське держ вне регіон льне геологічне підприємство, 2003.

iдmun 2.1. о скл ду підтипу н леж ть суміжні р йони, розт шов ні н південному з ході обл сті, - к довський т юрупинський. ля цих територій прит м нн н дзвич йно висок ч стк земель, сконцентров них в , - м йже вдвічі більш від середньообл сного пок зник (коефіцієнт концентр ції ст новить 1,84). собливостями спеці ліз ції рослинництв цього підтипу є: дуже низьк концентр ція зернових культур (н йнижчий пок зник після типу ); висок (порівняно з обл стю) ч стк земель під овочевими, б шт нними культур ми т к ртоплею, зумовлен незн чними обсяг ми вирощув ння зернових культур; н йвищ у ерсонському регіоні ч стк земель, сконцентров н під 6 шт нними культур ми (коефіцієнт концентр ції - 3,04). исок концентр ція пр цемістких культур у підтипі, сл бкий розвиток кормової б зи зумовили незн чний рівень розвитку тв ринництв, перш 3 все скот рств . ідносн кількість худоби н віть нижч, від приміського типу і ст новить 0,13 , тоді як середнє по типу $-0,26$. стк корів у структурі більш від середньої по типу і ст новить 0,72 .

огляду н з зн чені особливості, цей підтип, певною мірою можн вв ж ти перехідним між типом і типом . в ж ємо, що цьому сприяє т кож геогр фічне положення і зн чн урб нізов ність р йонів підтипу.

iдmun 2.2. о цього підтипу н леж ть олоприст нський, ововоронцовський, овотроїцький дміністр тивні р йони. собливості підтипу визн чені т кими спект ми функціонув ння : висок ч стк земель, сконцентров н в , - н $15 \%$ більш , ніж у середньому по обл сті; спеці ліз ція рослинництв м йже тотожн з підтипом 2.1, проте збільшен ч стк зернових і зменшен ч стк овочевих і 6 шт нних культур, що зумовлене кон'юнктурою ринку і змін ми геогр фічного положення щодо ринків збуту; щодо попереднього підтипу спостеріг ють збільшення вдвічі поголів'я худоби, свиней - н $280 \%$ (другий пок зник серед виділених т ксонів), що пояснюють збільшенням ч стки зернових культур як основних кормів; н явне скорочення н $5 \%$ корів у 
структурі , що, н н ш погляд, зумовлене зменшенням ч стки міського н селення в з зн чених регіон х т відд леністю від міст як основних центрів збуту молочної продукції.

iдmun 2.3. о скл ду підтипу з числені ілозерський, енічеський, л нч цький дміністр тивні р йони. пецифічною рисою цього підтипу є менш н $40 \%$ від середньотипового пок зник ч стк земель, сконцентров них в · одноч с, зн чно зрост ють щодо середньотипових коефіцієнти лок ліз ції зернових культур (пок зник по підтипу - 0,97). сновними г лузями спеці ліз ції з лиш ються овочівництво (коефіцієнт лок ліз ції - 1,27) і к ртоплярство $(1,84)$, б шт нництво м є зн чно менший розвиток.

оловними рис ми розвитку тв ринництв є висок чисельність поголів'я великої т м лої рог тої худоби, причому м $є$ н йвищий в обл сті пок зник кількості голів н особу $(0,21)$. е пов'яз но перш $з$ все $з$ тим, що з зн чен г лузь є тр диційною г луззю тв ринництв у приморських р йон х. Зн чимо т кож, що ч стк корів, незв ж ючи н зн чний розвиток скот рств , $є$ н йменшою в типі.

ип : периферійний. икон н кл стериз ція д л змогу об'єдн ти в цей тип ерисл вський, еликолепетиський, еликоолекс ндрівський, ерхньорог чицький, исокопільський, орност ївський, в нівський, ховський, ижньосірогозький т плинський дміністр тивні р йони ерсонської обл., розподіливши їх н дв підтипи.

ля типу х р ктерним є нижч н $8 \%$ від середньообл сної ч стк земель, зосереджених в · еред головних н прямів спеці ліз ції рослинництв, прит м нних обл сті, у цьому типі виявляється як тов рний лише зерновий н прям рослинництв .

ожливі причини сформов ної спеці ліз ції рослинництв т кі: незн чн щільність н селення в регіоні, що зменшує в ртість земель і зумовлює рент бельність зернового н пряму господ рств ; відсутність дост тньої кількості трудових ресурсів, як ускл днює розвиток пр цемістких г лузей рослинництв ; з г лом менший розвиток зрошув ння по регіон х типу, що обмежив можливості вирощув ння овочевих, б шт нних культур і к ртоплі.

зн чимо, що для типу х р ктерною $є$ н йвищ кількість голів свійських тв рин (пр ктично всі пок зники в 2 р зи більші, ніж у попередніх тип х). одноч с, н йнижчою є ч стк корів у структурі $-59 \%$. е пояснюють т кими 3 г льними для ерсонської обл. 3 г лом тенденціями: з відд ленням від міських поселень i, особливо, від обл сного центру збільшується кількість голів худоби н член 3 0,15 в приміському типі до 0,45 у периферійному; від центру до периферії відбув ється скорочення ч стки корів у структурі з 84 до $59 \%$; н дзвич йно збільшується м йже в 6 р зів - кількість свиней н особу: з 0,06 (у приміському типі) до 0,34 (у периферійному типі).

пецифічні риси природокористув ння цього типу поляг ють у декількох спект х. о-перше, для територій, у меж х яких функціонують , х р ктерний дуже високий рівень сільськогоспод рського освоєння (від 79,2 до 96,4 \%). о-друге, н дзвич йно високою є розор ність території - до 90,0 \% (у ижньосірогозькому р йоні). к ситу ція призводить до з гострення проблем дегр д ції грунтів, що з фіксов но і в меж $\mathrm{x}$ i, Як звич йно, нег тивно позн ч ється н продуктивності сільськогоспод рських угідь особистих господ рств.

собливості просторової диференці ції т розвитку особистих господ рств дміністр тивно-територі льних одиниць обл сті д ли змогу виділити в меж х типу дв підтипи. 
iдmun 3.1. о цього підтипу з числено ерисл вський, орност ївський т плинський дміністр тивні $\mathrm{p}$ йони. $\mathrm{p}$ ктерними рис ми розвитку рослинництв в цього підтипу є т кі: н явність двох н прямів спеці ліз ції рослинництв - н зернових культур х т вирощув нні к ртоплі; більш висок, ніж з г лом по типу, концентр ція овочевих культур - 3 з г льного по типу рівня концентр ції 0,49 для підтипу х р ктерний пок зник 0,65; вдвічі більш концентр ція б шт нних культур - 0,44 з мість 0,22 у середньому по типу.

собливістю розвитку тв ринництв підтипу є дуже низькі (порівняно $з$ типом 3 г лом) пок зники розвитку окремих г лузей тв ринництв, с ме: н $40 \%$ менш відносн чисельність вз г лі т корів зокрем чисельність голів $\quad$ н особу ст новить 0,45 , в цьому підтипі - 0,28. к ж пропорція спостеріг ється і в чисельності корів - 0,25 т 0,16 відповідно. тричі нижч відносн кількість свиней, ніж по типу, $-0,11$ голів н член типу, відповідно.

івень розвитку інших г лузей тв ринництв пр ктично тотожний з середньотиповим.

iдmun 3.2. скл ді підтипу виділено еликолепетиський, еликоолекс ндрівський, ерхньорог чицький. исокопільський, в нівський, ховський, ижньосірогозький дміністр тивні р йони ерсонської обл.

г лом - це н йменш “міський” т н йбільш периферійний підтип, він є м йже нтиподом підтипу 1.2. ідрізняється моноспеці ліз цією н вирощув нні зернових культур, коефіцієнт лок ліз ції зернових ст новить 1,21 - з г лом, це н йбільший пок зник по обл сті. нші коефіцієнти лок ліз ції сільськогоспод рських культур менші, ніж по типу і є одними 3 н йменших в обл сті. оефіцієнт лок ліз ції к ртоплі ст новить 0,75 (не вр ховуючи трохи нижчого пок зник дуже м лого 3 площею підтипу 1.2 $(0,67)$, це н йнижчий пок зник в обл сті). ок ліз ція овочевих культур - 0,43, це мінім льний пок зник серед підтипів. кож дуже низьк концентр ція б шт нних культур $-0,12$.

томість основні пок зники тв ринництв не тільки н йбільші в типі, й є н йбільшими в ерсонському регіоні з г лом. прикл д, відносн чисельність $\quad(0,52$ голів худоби н член ) вдвічі більш, ніж у типі, і в 3,5 p 3 більш, ніж у типі . орів м йже вдвічі більше ніж у типі, т в 2,3 р 3 - ніж у типі . е більш вр ж юч різниця простежен у відносній чисельності свиней - відносний пок зник поголів'я в 2,5 р $з$ більший, ніж у типі , т в 7,5 p 3 - ніж у типі . к і в підтипі 3.1, спостережено низьку відносну чисельність корів у структурі $-59 \%$.

тже, типіз ція і под льше зонув ння території ерсонської обл. 3 особливостями територі льної орг ніз ції, спеці ліз ції т функціонув ння д ли змогу створити моделі просторових змін спеці ліз ції рослинництв і тв ринництв . зн чимо, що просторові зміни як у рослинництві, т к і в тв ринництві відбув ються 3 двом умовними “трендовими” осями, які проходять від центру до периферії з т кими н прям ми: довг вісь - від центру н північний схід, коротк - від центру н південь.

1. дміністр тивно-територі льний устрій обл сті т чисельність н явного н селення: т тист.

зб. ерсон, $2001.53 \mathrm{c}$.

2. ойко . ., орний . . кологія ерсонщини: вч. посібник. ерсон: epp , 2001. 156 с. 
3. ушнір . . озвиток особистих господ рств н селення в умов х перехідної економіки: втореф. дис... к нд. екон. н ук. ьвів, 1999. 18 с.

4. рмуль . . есто личного подсобного хозяйств в обеспечении обл стной продовольственной прогр ммы / еп. в гропром. ., 1986. 17 с.

5. рирод ерсонської обл сті: ізико-геогр фічний н рис / ідп. ред. . . ойко. . . ітосоціоцентр, $1998.120 \mathrm{c}$.

6. рогр м розвитку земельної реформи в ерсонській обл сті н 2002-2005 pp. ержкомзем кр їни: ерсонське обл сне упр вління земельних ресурсів. ерсон, 2002.

7. еформув ння земельних відносин в ерсонській обл сті: нформ ційно- н літичні м тері ли. ерсон, 2003. 58 c.

\title{
FEATURES OF TERRITORIAL ORGANIZATION OF THE INDIVIDUAL FARMS OF POPULATION ON EXAMPLE OF KHERSON REGION
}

\author{
Kherson State University, \\ 40 rokiv Zhovtnya St., 27, UA - 79000 Kherson, Ukraine
}

\section{Bogadyorova}

It was presented the territorial organization of individual farms of population (IFP) on the local level. According to the researches of the social-geographical and nature-ecological factors of the development of IFP in Kherson region, analysis of branch structure, specificity of land-tenure, it is made the typological zoning of the territory of Kherson region which is based on the peculiarities of the development and functioning of individual farms.

Key words: individual farms, territorial organization, individual farms of population (IFP), specificity of land-tenure.

\section{- ог дёров}

ерсонский госуд рственный университет, ул. 40 лет ктября, 27, г. ерсон, 73000, кр ин

сследов но территори льную орг низ цию личных хозяйств н селения н лок льном уровне. основ нии исследов ния общественно геогр фических и естественно экологических ф кторов р звития личных хозяйств ерсонской обл., н лиз отр слевой структуры, специфики землепользов ния, проведено типологическое зониров ние территории ерсонской обл. 3 особенностями р звития и функциониров ния хозяйств.

лючевые слов : личные хозяйств н селения, территори льн я орг низ ция, , специлиз ция.

т ття н дійшл до редколегії 03.05.2009 рийнят до друку 20.09.2009 